\title{
The Relationships Among Physiological Characters and Productivities of Nine Pgl Clones in Medium Land
}

\author{
Ika Irmayanti*, Didik Indradewa, Eka Tarwaca Susila Putra \\ Faculty of Agriculture, Universitas Gadjah Mada, Bulaksumur, Yogyakarta, Indonesia 55281. \\ *email: irmayantiika@yahoo.com
}

\begin{abstract}
The objectives of the study were to determine the relationships among the physiological characters and productivities of nine PGL clones in medium land. Field trial was arranged in a Randomized Complete Block Design (RCBD) single factor with three blocks as replications. The treatment was PGL clones, consisting of nine clones, namely PGL 1 PGL 3, 4 PGL, PGL 7, PGL 10, PGL 11, PGL 12, PGL 15, and PGL 17. The observations were done on several variables of physiological characters and productivities. Data were analyzed by using the Analysis of Variance (ANOVA) at 5\% levels. If there were significant differences among the treatments, they will be analysed by Duncan Multiple Range Test (DMRT). The relationships among variables were determined using correlation analysis. Results showed that there were wide variations in the stomatal density and width openings and also productivities among the nine PGL clones. Stomatal density and width openings have significant positive correlation with the productivity. PGL 12 and 15 with a denser of stomatal arrangement and wider stomatal openings have higher productivities when compared to other PGL clones, especially PGL 7 with the most loosely stomatal arrangement and narrower stomatal openings.
\end{abstract}

Keywords: PGL clones, physiological character, and productivity

\section{INTRODUCTION}

Tea (Camellia sinensis L. Kuntze) is one of the plantation crop that is gaining attention from the state, private sector and farmers because the price of tea in the overseas market quite well. Indonesian tea prices at the global level began to improve by an average of USD $1.4 / \mathrm{kg}$, which was previously at the level of USD $1.2 / \mathrm{kg}$ (Anonymous, 2004). Tea used as a material of beverages that much-loved, because of fragrant aroma and distinctive taste (Anonymous, 1996).

The main problem encountered in tea breeding is a long time period to identify the yield potential of a clone, because it's cross pollinated, so that the phenotypic character is influenced by the environment (Bezbaruah, 1984 cit Sriyadi et al., 1993). Currently, in Indonesia, the effort to get superior tea clones has generated thousands of F1 from artificial crosses. However, the most of F1 has not been characterized, especially with the regard to the physiological characteristics and productivities as well as the relationship among them. Therefore, research on the characterization of physiological properties and productivities as well as the relationship among them are important to be done, to determine the tea clones with excellence physiological characteristics and high yield.

Some of the indicators that reflect the quality of the tea include aroma, taste and colour of steeping. The characters are determined by the chemicals compounds inside the teas. Such chemicals compounds are formed during the growth of shoots or in the process of fermentation within processing (Sanderson \& sivapalan, 1966; Yamanishi, 1984 cit Kasim, 2007). Biosynthesis of organic acids such as amino acids involves a number of enzymes and one of them is the nitrate reductase (NR). This enzyme acts as a biocatalyst in the $\mathrm{N}$ metabolism. Nitrate reductase has a role in providing an ammonium group $\left(\mathrm{NH}_{4}^{+}\right)$that was required for amination of $\alpha$-keto-glutaric acid into glutamic acid through the reduction of nitrate $\left(\mathrm{NO}_{3}^{-}\right)$(Pituati, 2005; Kasim, 2007).

Wickremasinghe et al. (1980) cit Kasim (2007) showed that there was a correlation between the nitrate reductase activities (NRA) with green leaf production. Clones with lower productivities of green leafs, have low levels of nitrate reductase activities. Nitrate reductase activity also can be used as criteria for the 
selection of clones that have the high productivity potential (Prawiranata et al., 1988; Sriyadi et al., 1993).

Leaf greenish is indicates the chlorophyll content in the leaf tissue. The leaf with higher chlorophyll content is greener than compare to the leaf with lower one. Higher leaf greenish correlated with higher photosynthetic activity. Shivashankar et al. (1985) cit Marzuqie (2007) states that higher NRA and chlorophyll content allows optimal leaf area development, so as to produce a greater dry matter.

Stomata characters can also be used as a key indicator of productivity of tea clones. Stoma is an organ that functions in the exchange of gases and water between the atmosphere and intercellular space system in the mesophyll tissues of leaves. Therefore, stoma has an important role in stomatal transpiration and photosynthesis activities (Swarthout, 2010). Stomatal pore movement caused by changes in the volume of guard cells which are governed by the entry and exit of $\mathrm{K}^{+}$and other ions from and to the guard cells during the process of opening and closing of stomata.

\section{MATERIALS AND METHODS}

The study was conducted in October 2011 January 2012 in Afdeling Kayulandak, UP. Pagilaran, PT. Pagilaran, Batang Regency, with the altitude \pm 1300 meters above sea levels. The research was arranged in a Randomized Complete Block Design (RCBD) single-factor with three blocks as replications. The treatment was tea clones, there were nine clones, namely PGL 1, PGL 3, PGL 4, PGL 7, PGL 10, PGL 11, PGL 12, PGL 15, and PGL 17. Each block contains nine experimental units, each of which represents the clones tested. Each unit of experiment using 20 bushes of tea, with a spacing of $120 \mathrm{~cm} \times 60 \mathrm{~cm}$. Plot sizes of samples used in each experimental unit were $1 \mathrm{~m} \times 1 \mathrm{~m}$, each using three samples per experimental unit.

The observations were done on the NRA, leaves greenish, stomatal density and width openings, the rate of photosynthesis and productivity. Data were analyzed using Analysis of Variance (ANOVA) at 5\% levels. If there were significant differences among the treatments, they will be analysed by Duncan Multiple range Test (DMRT). The relationships among variables were determined using correlation analysis.

\section{RESULTS AND DISCUSSION}

Table 1 provides information that nine clones of PGL tested in this study have the similar NRA, leaves greenish, and photosynthesis rate. The significant differences among the nine clones of PGL were found in the characters of stomatal density and width openings. Results of this study were inconsistent with Mitrowihardjo (2012) which states that the PGL 15 has higher NRA when compared to others PGL clones.

Table 1 also provides information that PGL 15 was a clone with the highest stomatal density and significantly different from others PGL clones, while PGL 12 was a clone with the most wide stomatal aperture. PGL 7 was a clone with smallest stomatal density and width opening. The rate of photosynthesis was the leaf photosynthetic capacity per unit leaf area in the state of light saturation, optimal concentration of $\mathrm{CO}_{2}$ and $\mathrm{O}_{2}$, optimum temperature and high relative humidity, with varying yields. Table 1 informed that there were no significant differences among the nine PGL clones in term of photosynthesis rate. These relate to the NRA and leaves greenish that also did not differ significantly among the nine PGL clones. Leaves greenish and NRA were homogeneous among the nine PGL clones, so that photosynthetic activities per unit leaf area were similar among the clones.

Nine PGL clones that tested have the diverse in productivities (Table 1). PGL 12 and 15 have the highest productivities, while PGL 7 has lower productivity when compared to others clones. The rate of photosynthesis per unit leaf area was not significantly different among clones because NRA and leaves greenish were also not significantly different.However, the productivities were significantly different among the clones. The differences among clones were caused by the different in photosynthetic capacity and leaf area per bush, as well as the density and width openings of stomatal (Neyra and Hageman, 1975; Gardner et al., 1991; Kaiser and Behnisch; 1991; Kramer, 1995; Shivashankar et al., 1985 cit Marzuqie, 1997; Kertasaputra, 1998; Foyer et al., 1998; Lawlor, 2001).

Table 2 provides information that productivities have significant positive correlation with the stomatal density and width openings. PGL clones that have higher stomatal density and wider stomatal openings were more higher productivities when compared to PGL clones with lower stomatal density and narrower stomatal 
openings. Table 1 provides information that PGL correlated with more tightly stomatal structured and wider stomatal openings when compared to others PGL clones (Table 2). While, PGL 7 has lower productivity when compared to others PGL
12 and PGL 15 have higher productivities as clones (Table 1) because it was correlated with more loosely stomatal structured and narrower stomatal openings (Table 2).

Table 1.NRA, leaves greenish, stomatal density and width openings, photosynthesis rate, and productivities of nine PGL clones

\begin{tabular}{|c|c|c|c|c|c|c|c|c|c|c|c|c|}
\hline \multirow{2}{*}{$\begin{array}{l}\text { Clones } \\
\text { PGL } 1\end{array}$} & \multicolumn{2}{|c|}{$\begin{array}{l}\text { NRA } \\
(\mu \mathrm{mol} \\
\mathrm{NO}_{2} \mathrm{~g}^{-} \\
\left.{ }^{1} \text { hour }^{-1}\right) \\
\end{array}$} & \multicolumn{2}{|c|}{$\begin{array}{c}\text { Leaves } \\
\text { Greenish } \\
\text { (SPAD } \\
\text { Unit) }\end{array}$} & \multicolumn{2}{|c|}{$\begin{array}{c}\text { Stomatal } \\
\text { density } \\
(\text { stomata } \\
\left.\mathrm{mm}^{-2}\right)\end{array}$} & \multicolumn{2}{|c|}{$\begin{array}{l}\text { Stomatal } \\
\text { width } \\
\text { openings } \\
(\mu \mathrm{m})\end{array}$} & \multicolumn{2}{|c|}{$\begin{array}{l}\text { Photosynthesi } \\
\mathrm{s} \mathrm{rate}(\mu \mathrm{mol} \\
\left.\mathrm{CO}_{2} \mathrm{~m}^{-2} \mathrm{~s}^{-1}\right)\end{array}$} & \multicolumn{2}{|c|}{$\begin{array}{l}\text { Productivity (g } \\
\left.\mathrm{m}^{-2} \text { plucking }^{-1}\right)\end{array}$} \\
\hline & 0.678 & $\mathrm{a}$ & 59.39 & $\mathrm{a}$ & 100.22 & $\mathrm{~g}$ & 0.015 & $\mathrm{e}$ & 98.66 & $\mathrm{a}$ & 9.250 & $a b$ \\
\hline PGL 3 & 0.857 & $\mathrm{a}$ & 60.99 & $\mathrm{a}$ & 120.67 & $\mathrm{e}$ & 0.022 & $\mathrm{c}$ & 97.66 & $\mathrm{a}$ & 10.379 & $a b$ \\
\hline PGL 4 & 1.042 & a & 59.54 & a & 110.00 & $\mathrm{f}$ & 0.028 & b & 105.58 & $\mathrm{a}$ & 10.301 & $a b$ \\
\hline PGL 7 & 0.654 & $\mathrm{a}$ & 57.79 & $\mathrm{a}$ & 79.33 & $\mathrm{~h}$ & 0.011 & $\mathrm{f}$ & 97.03 & a & 6.969 & b \\
\hline PGL 10 & 1.068 & $\mathrm{a}$ & 61.73 & a & 135.33 & d & 0.019 & $d$ & 101.33 & $\mathrm{a}$ & 10.385 & $a b$ \\
\hline PGL 11 & 1.056 & $\mathrm{a}$ & 63.09 & $\mathrm{a}$ & 155.78 & $\mathrm{c}$ & 0.023 & $\mathrm{c}$ & 102.26 & $\mathrm{a}$ & 10.726 & $a b$ \\
\hline PGL 12 & 1.144 & $\mathrm{a}$ & 63.14 & a & 173.56 & b & 0.031 & $\mathrm{a}$ & 109.23 & $\mathrm{a}$ & 13.409 & $\mathrm{a}$ \\
\hline PGL 15 & 1.279 & $\mathrm{a}$ & 63.26 & $\mathrm{a}$ & 224.67 & $\mathrm{a}$ & 0.029 & $a b$ & 120.73 & $\mathrm{a}$ & 13.547 & $\mathrm{a}$ \\
\hline PGL 17 & 0.907 & $\mathrm{a}$ & 59.59 & $\mathrm{a}$ & 117.11 & e & 0.022 & $\mathrm{c}$ & 102.90 & $\mathrm{a}$ & 10.305 & $a b$ \\
\hline Mean & \multicolumn{2}{|c|}{0.965} & \multicolumn{2}{|c|}{60.95} & \multicolumn{2}{|l|}{135.19} & \multicolumn{2}{|c|}{0.022} & \multicolumn{2}{|l|}{103.93} & \multicolumn{2}{|c|}{10.585} \\
\hline CV (\%) & \multicolumn{2}{|c|}{14.26} & \multicolumn{2}{|c|}{5.30} & \multicolumn{2}{|l|}{2.80} & \multicolumn{2}{|c|}{6.270} & \multicolumn{2}{|l|}{13.78} & \multicolumn{2}{|c|}{24.789} \\
\hline
\end{tabular}

Note : The means in one column followed by the same letter were not significantly different according to DMRT ( $\alpha$ 5\%)

Table 2. The correlation among variables

\begin{tabular}{lrrr}
\hline Variables & $\begin{array}{c}\text { Stomatal density } \\
\left(\text { stomata } \mathrm{mm}^{-2}\right)\end{array}$ & $\begin{array}{r}\text { Stomatal width } \\
\text { openings }(\mu \mathrm{m})\end{array}$ & $\begin{array}{c}\text { Productivity }\left(\mathrm{g} \mathrm{m}^{-2}\right. \\
\left.\text { plucking }^{-1}\right)\end{array}$ \\
\hline Stomatal density $\left(\right.$ stomata $\left.\mathrm{mm}^{-2}\right)$ & 1.000 & & \\
Stomatal width openings $(\mu \mathrm{m})$ & $0.755^{*}$ & 1.000 & \\
Productivity $\left(\mathrm{g} \mathrm{m}^{-2}\right.$ plucking & & & \\
\hline Notes: $\mathrm{r}_{.05(25)}=0,381$ & $0.528^{*}$ & $0.531^{*}$ & 1.000 \\
\hline
\end{tabular}

Stomata were arranged closer and open wider allowing the smooth rate of diffusion of gases, especially $\mathrm{CO}_{2}$ into the leaf mesophyll and $\mathrm{O}_{2}$ out of the leaf mesophyll. Tea which is a group of $\mathrm{C} 3$ plants take advantage of this situation because of pacing to the photosynthetic activity per individual plant. The increase in photosynthetic activity per individual plant has the potential to increase the productivity. So that, PGL 12 and PGL 15 with more tightly stomatal arrangement and wider stomatal openings were have higher productivities when compared to others PGL clones, especially PGL 7 with the loosely stomatal arrangement and narrower stomatal openings ( Gardner et al. , 1991; Kaiser and Behnisch; 1991; Kramer, 1995; Shivashankar et al., 1985 cit
Marzuqie, 1997; Foyer et al., 1998; Lawlor, 2001).

\section{CONCLUSION}

There were wide variations in the stomatal density and width openings and also productivities among the nine PGL clones. Stomatal density and width openings have a significant positive correlation with the productivity. PGL 12 and 15 with a denser of stomatal arrangement and wider stomatal openings were have higher productivities when compared to other PGL clones, especially PGL 7 with the most loosely stomatal arrangement and narrower stomatal openings. 


\section{ACKNOWLEDGEMENTS}

This research work was funded by Faculty of Agriculture, Universitas Gadjah Mada, under the Research University Grant Scheme (Project No. 085/Dir.Keu/KN/DIPA-UGM/2011). The authors would like to express their gratitude to Mr. Widodo for his assistance in the study.

\section{REFERENCES}

Anonim. 2004. Harga Jual Teh Republik Indonesia Membaik. www.nafed.go.id.

Anonim. 1996. Vademecum Teh. PT Perkebunan Nusantara IV. Medan

Foyer, C. H., Valadier, M. H. and Becker, T. W. 1998. Drought Induced Effect on Nitrate Reductase Activity an mRNA and on teh Coordintaion of Nitrogen and Carbon Metabolism in Maize Leaves. Plant Physiol. (117) : 293-302

Gardner, F. P., Pearce, R. B., dan Mitchell, R. L. 1991. Fisiologi Tanaman Budidaya. Penterjemah Susilo, H. Indonesia Press.

Jones, H. G. 1998. Stomatal Control of Photosynthesis and Transpiration. Journal of Experimental Botany, Vol. 49, Special Issue, pp. 387-398. Oxford University Press.

Kaiser, W. andBrenle Behnisch, E. 1991. Rapid Modulation of Spinach Leaf Nitrate Reductase Activity by Photosynthesis. Plant Physiol (96) : 363-367.

Kasim, M. H. 2007. Pengaruh Pemupukan Terhadap Aktifitas Nitrat Reduktase dan Laju Pertumbuhan Pucuk Pada Tanaman Teh (Camellia sinensis L.). Tesis Pascasarjana (tidak dipublikasikan). Universitas Gadjah Mada.

Kramer, P. J and Boyer, J. S. 1995. Water Relation of Plant and Soils. Academic Press, San Diego.
Lawlor DW. 2001. Photosynthesis: Molecular, Physiological And Environment Processes, 3rd edn. Oxford, UK: Bios Scientific Publishers.

Marzuqie, S. F. 1997. Pengaruh Lengas Tanah dan Dosis Nitrogen terhadap Aktifitas Nitrat Reduktase Daun, Pertumbuhan dan Kualitas Biji Jagung Manis (Zea Mays saccharata Sturt.). Tesis. Universitas Gadjah Mada. Yogyakarta.

Mitrowihardjo S. 2012. Kandungan katekin dan hasil pucuk beberapa klon teh (Camelia sinensis (L.) O. Kuntze) unggulan pada ketinggian yang berbeda di kebun Pagilaran. Disertasi Program Studi Pemuliaan Tanaman. Fakultas Pertanian UGM. Yogyakarta.

Pituati, G. 2005. Penagruh Nisbah Nitrat dan Amonium Terhadap Aktifitas Nitrat Reduktase, Kandungan N, Pertumbuhan dan Hasil tanaman Pak Choi (Brassica sinensis L.). Tesis. Universitas Gadjah Mada. Yogyakarta.

Pugnaire, F.I., and J. Pardos. 1999. Constrains by Water Stress on Plant Growth. In Parassakli, M. (ed.) Hand Book of Plant and Crop Stress. John Willey \& Sons. New York.

Prawiranata, W., Harran, S., Tjondronegoro, P. 1988. Dasar-Dasar Fisiologi Tumbuhan. Jilid I. Departemen Botani Fakultas Pertanaian. Institut Pertanian Bogor.

Sriyadi, B., Baihaki, A., Setiamihardja, R., Astika, W. 1993. Aktivitas Nitrat Reduktase sebagai Penduga Potensi Hasil Klon-Klon Teh. Zuriat. Vol. 4, No. 1, Januari-Juni.

Swarthout, D. 2010. Stomata. Teh Encyclopedia ofEarth.http://www.eoearth.org/view/article/ 156262/ 